than any that had ever plagued " the secret epirit of the adepts." There was no short cut to longevity. To win it was the work of a lifetime, and the promotion of it was a branch of public medicine. Perchance one of these days we should have an International Congress on Old Age, with an exhibition of dotards for warning and of hale and hearty centenarians for encouragement. At any rate, they might rest assured that it was by a steady obedience to the general laws of health that old age might be attained, and by judicious regimen that it might be prolonged. The measures necessary for the promotion of old age on the large scale lay beyond the control of the medical profession. They could not always change the spirit of the age, abolish avarice, vainglory, and the lust of power, or quell even the gratuitous excesses of the struggle for existence that raged around; but they could do something by pointing out to those who would listen to them some great perils that might be avoided, and they could also give the weight of their support to all movements tending towards the betterment of our race. He instanced as a movement of that kind specially related to his theme that day the project for national insurance against old age which Mr. Chamberlain had done so much to advance. Life insurance had, by the tranquillity of mind which it had conferred on those who had taken advantage of it, done much to avert madness and prolong life, and national insurance against old age by removing apprehensions that must sometimes harass even the bucolic mind apprehensive of pauperism, so ignominious to an Englishman when work was done, would, he was confident, conduce widely to the attainment of sound and pleasurable old age.

\section{SHEFFIELD SCHOOL OF MEDICINE.}

ADDRESS BY MR. W. F. FAVELL, J.P.

THE sixty.fourth session of the Sheffield School of Medicine was opened on Oct. 1st, when Mr. W. F. Favell, J.P., the President of the School, gave the inaugural address at Firth College. The chair was occupied by Mr. Arthur Jackson. The large hall was well filled with medical gentlemen and students.

Mr. FAVELL, who had a hearty reception, said that when his colleagues did him the honour of asking him to open the session this year he felt that he could not decline. He owed so much of the happiness of his life, and no small measure of what success he had attained, to the kindly feeling and ready help of his medical brethren that it was both a duty and a pleasure to show his gratitude by complying with any request they might make so far as it lay in his power. In entering upon his address, he could hardly help comparing the present condition and equipments of the Sheffield School of Medicine with its condition when he was a student forty years ago, nor could he help congratulating those who were now actively engaged in teaching on the most satisfactory and encouraging state of the school. Not only was it numerically stronger than it had ever been before, but the teaching staff had been greatly strengthened by the addition of able and enthusiastic young men; and their connexion with the Firth College had enabled them to get valuable help in scientific teaching from several of its distinguished professors. All who were engaged in teaching in his student days were gone, but the memory of some of them would be a joy to him as long as he lived. The last, his old friend, Dr. Bartolomé, departed buta yearand a half ago; no more able, assiduous, and regular lecturer ever existed. These reminiscences of bygone days brought forcibly to his mind the truth of Dr. Gatty's remarks when he said, "One of the penalties of longevity is that we outlive our friends, and we have not the heart to make new ones." Nevertheless, it was pleasant to see amongst the names of the very able and active working staff of the present School of Medicine the sons of some of the men who did such good work in the old school. They had now infinitely better and more commodious premises in which to carry on their studies, but he wished he could see the new school out of debt. He thought he should. The names of Jessop and Wake would be remembered as long as the charities which were the recipients of their munificent generosity lasted, and he ventured to think that the efficiency of an educational centre for the training of those who were destined, in all probability, to be the future physicians and surgeons to those charities was a matter of no small concern to the inhabitants of Sheffield. But some might ask, Was it a good thing to have these provincial medical schools? Were they worth supporting, and did they work well for the public and the medical pro. fession? The arguments urged against provincial schools were that the teachers holding chairs in the great metro. politan schools were men of acknowledged eminence; that the equipment of the metropolitan schools was as perfect as it could be; and that the students there had advantages which provincial schools could not command. But he urged that, on the other hand, provincial schools possessed advan. tages over the metropolitan schools. In towns like Sheffield, great manufacturing centres, there was enormous material for teaching, the value of which could not be over. estimated, and which it seemed almost a sin not to utilise. In their school they had the most important requisites for imparting a thoroughly sound, practical, and scientific training. In small schools like theirs students were neces. sarily brought into closer personal contact with the teachers than they could be in the great London schools; and they had therefore a better chance of receiving a more thorough and practical grounding in their work. A man might be a thorough master of the scientific side of his pro. fession, but if he had not had the opportunity of practical acquintance with disease and injury, under some com. petent master, he would find himself at sea when he commenced the practice of his profession. He uften felt himself appalled when he thought of the responsibilities that rested on the shoulders of the medical man what a power for good or for evil he might be; and he could not too strongly emphasise his conviction that before any young man received a diploma anthorising him to practise he ought to be compelled to produce evidence of having spent twelve months in the careful study of disease at the bedside of patients, under the supervision and guidance of an experienced and competent medical man. But another point in favour of provincial schools was that young men were offered the advantages of a sound and practical train. ing witbout being withdrawn from home discipline and home influence. A last reason: the schools were a benefit to the profession and the community because they guaranteed to the public the existence of a staff of medical men who must keep well abreast with the discoveries and advances in medical and surgical science and practice. To the students of the school he would address a few words of advice and encouragement. The medical profession was one full of interest and full of charm to those who bad a taste for it, but he could imagine it being very distasteful to those who entered it without having any love for the work. The five years they had to devote to study was not one bit too long; there was so much to learn and the responsibilities to be incurred were so great. He rentured to express the confident hope that with the training they would get at the Sheffield school it would be their own fault if they did not commence the work of life as well armed for the struggle as any young men could be. They would find, however, if their curriculum extended over fifty and five years, instead of only five, how much they still had to learn. the medical man was a student all his life. Looking beyond their student life, he would say that nothing was more important than that a young man commencing practice should have a deep sense of professional morality and integrity; that he should be guided by the upright and honourable instincts of a gentleman in his relations with his medical brethren, and at the same time that he should have a keen appreciation of his duties and obligations to the public. He was aware that the present struggle for existence was a very severe one. It had been said that the average London medical man only began to make his bread and cbeese when he had lost his teeth wherewith to eat it. But be believed, by patience and stricb attention to work, it was open to all of them to make a competence but he warned them not to let their impatience for success lead them to adopt unworthy means to secure it. They might gain some temporary success, but they would not succeed to their own satisfaction, nor would they secure the confidence of those whose good opinions they most highly valued. What he believed would help them to attain this object more than anything else was to cultivate a spirit of true and genuine sympathy. He was afraid that many young men, in strong and vigorous health, were not very sympathetic. Let him beg of them not to let familiarity with suffering blunt their feelings of sincere sympathy with the sufferer. The profession they were just entering was indeed worthy of the most devoted and persevering study, for it was a high and a holy calling. 